\title{
SS18/SSX4 Fusion Protein
}

National Cancer Institute

\section{Source}

National Cancer Institute. SS18/SSX4 Fusion Protein. NCI Thesaurus. Code C99398.

A fusion protein (492 aa, $\sim 54 \mathrm{kDa}$ ) encoded by the SS18/SSX4 fusion gene. This protein is comprised of all but the last 8 amino acids of the C-terminus of protein SSXT, fused to the last 78 C-terminal amino acids of protein SSX4, including the SSX transcription repression domain. 